\title{
Samoa Standard Time
}

National Cancer Institute

\section{Source}

National Cancer Institute. Samoa Standard Time. NCI Thesaurus. Code C116270.

Local standard time, based at the 165th meridian west of the Greenwich Observatory, established as eleven hours behind Coordinated Universal T ime. 